\title{
STABILITY OF SYSTEMS OF SINGULAR INTEGRAL EQUATIONS WITH CAUCHY KERNEL
}

DOI: $10.36724 / 2072-8735-2020-\mid 4-9-48-55$

\author{
Aleksey V. Yudenkov, \\ Smolensk State Academy of Physical Culture, Sport and Tourism, \\ Smolensk, Russia, aleks-ydenkov@mail.ru
}

\author{
Aleksandr M. Volodchenkov, \\ Smolensk Branch of Plekhanov Russian University of Economics; \\ 3Smolensk Branch of Saratov State Law Academy, \\ Smolensk, Russia, alexmw20I2@yandex.ru \\ Liliya P. Rimskaya, \\ Smolensk Branch of Plekhanov Russian University of Economics, \\ Smolensk, Russia, aleks-ydenkov@mail.ru
}

Manuscript received 03 June 2020;

Accepted 28 August 2020

Keywords: elasticity theory, singular integral equations, stability theory, boundary problems for analytic functions, singular Cauchy integral

\begin{abstract}
Singular Cauchy integral equations have been widely used for mathematical simulation of the actual physical and technical systems. They are considered universal at every level of simulation beginning with quantum field theory and up to strength analysis of the underground constructions. Therefore investigating system stability of such models under perturbation of their absolute terms and coefficients appears an urgent scientific task. The aim of the study is to show various aspects of stability of singular Cauchy integral sets of equations which are generalizing simulation models of the primal problems of the elasticity theory for homogeneous isotropic bodies. The methods of study are based on the properties of the Cauchy singular integral, on the general theory of Fredholm operators. When in use, systems of the singular integral equations are reduced to a set of Fredholm integral equations of the second kind and a set of the boundary value problems for analytic functions. The key results of the study are the following: development of the general determination method of the system index for singular integral equations, proof of the system stability against perturbations of the absolute terms of the set. Against perturbations of the boundary coefficients, the singular integral system is unstable. Demonstration of the stability of the singular integral Cauchy sets generalizing primal problems of the elasticity theory appears a significantly new result. The research of singular integral equations sets has been performed conducted on the space of functions satisfying the Holder condition. However the main research results prove to be true if we operate random functions converting in mean square. Stability of singular integral equations sets against perturbations of the absolute terms lays a foundation for calculus of approximations in real world tasks of defining the built-in stress of an elastic complex body.
\end{abstract}

Information about authors:

Aleksey V. Yudenkov, Smolensk State Academy of Physical Culture, Sport and Tourism, Head of the Department of Management and Sciences, doctor of physics and mathematics, professor, Smolensk, Russia

Aleksandr M. Volodchenkov, Smolensk Branch of Plekhanov Russian University of Economics, Head of the Department of Sciences and Humanities, candidate of physics and mathematics, associate professor; Smolensk Branch of Saratov State Law Academy, assistant professor of the Department of Humanities, Socio-economical Sciences, Information Technologies and Law, Smolensk, Russia

Liliya P. Rimskaya, Smolensk Branch of Plekhanov Russian University of Economics, assistant professor of the Department of Management and Customs, candidate of physics and mathematics, associate professor, Liliya Pavlovna

\section{Для цитирования:}

Юденков А.В., Володченков А.М., Римская Л.П. Устойчивость систем сингулярных интегральных уравнений с ядром Коши // Т-Сотт: Телекоммуникации и транспорт. 2020. Том 14. №9. С. 48-55.

For citation:

Yudenkov A.V., Volodchenkov A.M., Rimskaya L.P. (2020) Stability of systems of singular integral equations with Cauchy kernel. T-Comm, vol. 14, no.9, pp. 48-55. (in Russian) 


\section{Introduction}

A singular Cauchy integral is given as:

$$
\frac{1}{2 \pi i} \int_{L} \frac{g(\tau) d \tau}{\tau-z} .
$$

Where (1) L is a subspace contour of the complex variable $\mathrm{z}=\mathrm{x}+$ iy defining domain $\mathrm{D} ; \tau$ is a contour point; function $\mathrm{g}(\tau)$ is integral density, formula $\frac{1}{\tau-z}$ is a kernel of the Cauchy integral.

Equation

$$
\begin{aligned}
& (K \omega)(t) \equiv a(t) \omega(t)+\frac{b(t)}{\pi i} \int_{L} \frac{\omega(\tau)}{\tau-t} d \tau+ \\
& +\int_{L} K(t, \tau) \omega(\tau) d \tau=g(t), \quad t \in L
\end{aligned}
$$

is a singular Cauchy integral equation ([5]c.171). In the equation (2) of the function $a(t), b(t)$ are boundary coefficients, $g(t)$ is a absolute term, $K(t, \tau)$ is a Fredholm kernel.

In many cases the use of singular integrals is limited according to the specific mathematical model that leads in its turn to emergence of singularities. For instance, given an indiscrete complex potential of some field, the problem is to work with a potential in a defined point. This leads to divergences. These may be eliminated turning to quantum computing or using the advantages of the complex space and properties of the singular Cauchy integrals.

Among all the complex potentials of the physical fields the most complicated potential is that of the elastic deformed body. In case with an isotropic body the complex potential is written as a bianalytic function: ([1],[19]):

$$
F(z)=\varphi_{0}(z)+\bar{z} \varphi_{1}(z)
$$

In the formula (3), $\varphi_{0}(z), \varphi_{1}(z)$ are analytic functions in the occupied by the body domain.

If the body is anisotropic, the complex potential is written more complicated ([6],[16]).

Traditionally they distinguish among three primal problems of the elasticity theory.

The first primal problem. Given outer forces on all surface, the problem is to calculate stresses and strains at every point inside a body and on its surface. Mostly there are three projections of forces on the reference directions $-X_{n}, Y_{n}, Z_{n}$ ( $n$ - outward normal; stress components per unit area)

Boundary conditions are written as:

$$
\begin{aligned}
& \sigma_{x} \cos (n, x)+\tau_{x y} \cos (n, y)+\tau_{x z} \cos (n, z)=X_{n}, \\
& \tau_{x y} \cos (n, x)+\sigma_{y} \cos (n, y)+\tau_{y z} \cos (n, z)=Y_{n}, \\
& \tau_{x z} \cos (n, x)+\tau_{y z} \cos (n, y)+\sigma_{z} \cos (n, z)=Z_{n} .
\end{aligned}
$$

The second primal problem. Assume projections of strains on all surface in three non-coincident directions, for example, projections $u^{*}, v^{*}, w^{*}$ on the Cartesian axes. The boundary conditions will be written as

$$
u=u^{*}, \quad v=v^{*}, \quad w=w^{*} .
$$

Mixed problem. Given forces on the part of the surface, and strains on the other, the boundary conditions for the first part of the surface will be given as (4), for the second part as (5). We also consider mixed such problems when we have one component of forces (normal, for instance) and two components of strains, or one component of strains and two components of forces, etc.

If for simulation we use boundary problems of the complex variable function theory and the corresponding sets of singular integral equations, then the three primal problems have similarities.

As for today the boundary problem theory and the corresponding sets of the singular integral equations are welldeveloped. However the conditions for stability and solvability of the systems have not yet been studied. At the same time the above issues appear extremely important when using mathematical simulation of the real world tasks.

The paper aims at testing the systems of singular Cauchy integral equations for stability and solvability.

\section{Problem statement}

The study is conducted on the class of functions satisfying Hölder condition.

The function $\phi(t)$ belongs to the Hölder class on the contour $L$, if for every two points of the contour the following condition is satisfied

$$
\left|\varphi\left(t_{2}\right)-\varphi\left(t_{1}\right)\right|<A\left|t_{2}-t_{1}\right|^{\mu}
$$

where $\mathrm{A}$ and $\mu$ are positive numbers. A is called the Hölder constant, $\mu$ is tthe Hölder criterion.

To be short, let us take $\phi(t) \in H_{\mu}^{(n)}(L)$. This means that the function $\phi(t)$ belongs to the Hölder class with its derivatives up to and including the order $n$.

Let us take that $0<\mu \leq 1$. Assume $\mu=1$, then the Hölder condition coincides with the known Lipschitz condition.

Assume $\mathrm{L}$ is a simple closed loop of the $\mathrm{C}_{\mu}^{(3)}$ class which defines the finite domain $\mathrm{D}^{+}$. The exterior infinite domain is $\mathrm{D}^{-}$. Consider the set of singular equations

$$
\begin{aligned}
& \left(K_{1} \omega_{1} \omega_{2}\right)(t) \equiv a_{1}(t)\left[\omega_{1}(t)+\bar{t} \omega_{2}^{\prime}(t)+\omega_{2}(t)\right]+ \\
& +\frac{d_{1}(t)}{\pi i} \int_{L} \frac{\omega_{1}(\tau)+\bar{t} \omega_{2}{ }^{\prime}(\tau)+\omega_{2}(\tau)}{\tau-t} d \tau+\int_{L} K_{11}(t, \tau) \omega_{1}(\tau) d \tau+ \\
& +\int_{L} K_{12}(t, \tau) \omega_{2}(\tau) d \tau=g_{1}(t)
\end{aligned}
$$




$$
\begin{aligned}
& \left(K_{2} \omega_{1} \omega_{2}\right)(t) \equiv a_{2}(t)\left[\omega_{1}(t)+\bar{t} \omega_{2}{ }^{\prime}(t)-\omega_{2}(t)\right]+ \\
& +\frac{d_{2}(t)}{\pi i} \int_{L} \frac{\omega_{1}(\tau)+\bar{t} \omega_{2}{ }^{\prime}(\tau)-\omega_{2}(\tau)}{\tau-t} d \tau+\int_{L} K_{21}(t, \tau) \omega_{1}(\tau) d \tau+{ }^{(6)} \\
& +\int_{L} K_{22}(t, \tau) \omega_{2}(\tau) d \tau=g_{2}(t), \quad t \in L
\end{aligned}
$$

where $\mathrm{K}_{\mathrm{k}, \mathrm{n}}(\mathrm{t}, \tau) \in \mathrm{H}^{(1)}(\mathrm{L} \times \mathrm{L}) ; \mathrm{a}_{\mathrm{k}}(\mathrm{t}), \mathrm{d}_{\mathrm{k}}(\mathrm{t}) \in \mathrm{H}^{(3-\mathrm{k})}(\mathrm{L}) ; \mathrm{g}_{\mathrm{k}}(\mathrm{t}) \in$ $\mathrm{H}^{(1)}(\mathrm{L})(\mathrm{k}, \mathrm{n}=1,2)$. Let us assume that the equations in the set are normalized, i.e. $\mathrm{a}_{\mathrm{k}}^{2}(\mathrm{t})-\mathrm{d}_{\mathrm{k}}^{2}(\mathrm{t}) \equiv 1$.

Find the functions $\omega_{1}(t), \omega_{2}(t)$.

Perform a preliminary analysis of (6).

The characteristical part of the set (6) corresponds to the Riemann primal boundary value problem for bianalytic functions ([5] c. 259).

A bianalytic function in some domain D (finite or infinite) is the function like

$$
F(z)=\varphi_{0}(z)+\bar{z} \varphi_{1}(z) .
$$

Here $\varphi_{k}(z)(\mathrm{k}=1,2)$ are analytic functions in the domain D or analytic components, $\bar{z}=x-i y$.

It is possible to say that a bianalytic function is a solution to a partial differential equation

$$
\frac{\partial^{2} F(z)}{\partial \bar{z}^{2}}=0
$$
tion.

Real part of a bianalytic function is called a biharmonic func-

The Riemann boundary value problem for bianalytic functions is written as:

$$
\begin{aligned}
& \varphi_{0}^{+}{ }^{\prime}(\mathrm{t})+\overline{\mathrm{t}}_{1}^{+}{ }^{\prime}(\mathrm{t})+\varphi_{1}^{+}(\mathrm{t})=\mathrm{G}_{1}(\mathrm{t})\left[\varphi_{0}^{-}{ }^{\prime}(\mathrm{t})+\overline{\mathrm{t}} \varphi_{1}^{-}{ }^{\prime}(\mathrm{t})+\varphi_{1}^{-}(\mathrm{t})\right]+\mathrm{Q}_{1}(\mathrm{t}), \\
& \varphi_{0}^{+\prime}(\mathrm{t})+\overline{\mathrm{t}}_{1}^{+} \varphi^{\prime}(\mathrm{t})-\varphi_{1}^{+}(\mathrm{t})=\mathrm{G}_{2}(\mathrm{t})\left[\varphi_{0}^{-}{ }^{\prime}(\mathrm{t})+\overline{\mathrm{t}}_{1}^{-\prime}(\mathrm{t})-\varphi_{1}^{-}(\mathrm{t})\right]+\mathrm{Q}_{2}(\mathrm{t}),
\end{aligned}
$$

where $G_{k}(t)=\frac{a_{k}(t)-d_{k}(t)}{a_{k}(t)+d_{k}(t)}, Q_{k}(t)=\frac{g_{k}(t)}{a_{k}(t)+d_{k}(t)}, \varphi_{k}^{ \pm}(t)$ are boundary values of the analytic constituents $\varphi_{\mathrm{k}}^{ \pm}(\mathrm{z})$ in the domains $\mathrm{D}^{ \pm}$correspondingly.

The correspondence between the boundary value problem and the characteristical part of the set (6) is expressed by the Cauchy integral of the type:

$$
\begin{aligned}
& \varphi_{0}^{\prime}(z)=\frac{1}{2 \pi i} \int_{L} \frac{\omega_{1}(\tau) d \tau}{\tau-z}, \\
& \varphi_{1}(z)=\frac{1}{2 \pi i} \int_{L} \frac{\omega_{2}(\tau) d \tau}{\tau-z} .
\end{aligned}
$$

Notice that the primal problem for bianalytic functions ([2], [11]) can be reduced to the boundary value problem (7) by the estimation method. Thus, the set (6) and the problem (7) can be considered generalized mathematical models of the primal problems in the elasticity theory for isotropic homogeneous bodies.
The key findings. Divide the study of the set of singular Cauchy integral equations into two parts. First estimate the number of solvability conditions and the number of the linearly independent solutions of the homogeneous set (6), defining its index. Second test the set (6) for stability against perturbations of the functions $g_{k}(t)$.

Index of the set of singular integral equations. The set of singular integral equations (6) and the Riemann boundary value problem (7) have a structure similar to standard vector sets and boundary value problems. However their solution is complicated by the presence of the non-analytic constituent $\bar{t}$ in the boundary conditions. This results in the fact that in the boundary value problem (7) the left-hand expressions and the bracketed expressions to the right of the equal are not analytic functions. Therefore in the given case the classic methods of study of the singular integral equation sets and the corresponding to them boundary problems for analytic vectors cannot be applied.

Let us suggest rather a simple method which allows to eliminate $\overline{\mathrm{t}}$ from the characteristical part of the set (6).

Handle the following preliminary conversion:

$$
\begin{aligned}
& \frac{1}{\pi i} \int_{L} \frac{\bar{t} \omega_{2}{ }^{\prime}(\tau) d \tau}{\tau-t}=\frac{1}{\pi i} \int_{L} \frac{\bar{\tau} \omega_{2}{ }^{\prime}(\tau) d \tau}{\tau-t}+ \\
& +\frac{1}{\pi i} \int_{L}(\bar{t}-\bar{\tau}) \frac{\omega_{2}{ }^{\prime}(\tau) d \tau}{\tau-t}=\frac{1}{\pi i} \int_{L} \frac{\bar{\tau} \omega_{2}{ }^{\prime}(\tau) d \tau}{\tau-t}+ \\
& +\frac{1}{\pi i} \int_{L}\left[\frac{\partial}{\partial \tau}\left(\frac{\bar{t}-\bar{\tau}}{\tau-t}\right)\right] \omega_{2}(\tau) d \tau .
\end{aligned}
$$

Note that the second addend in the right-hand part of the congruence possess quite a weak singularity. The first addend is a boundary value of the Cauchy singular integral.

Considering the above, the set (6) will be written as:

$$
\begin{aligned}
& \left(K_{1} \omega_{1} \omega_{2}\right)(t) \equiv a_{1}(t)\left[\omega_{1}(t)+\bar{t} \omega_{2}{ }^{\prime}(t)+\omega_{2}(t)\right]+ \\
& +\frac{d_{1}(t)}{\pi i} \int_{L} \frac{\omega_{1}(\tau)+\bar{\tau} \omega_{2}{ }^{\prime}(\tau)+\tau \omega_{2}(\tau)}{\tau-t} d \tau+ \\
& +\int_{L} K_{11}(t, \tau) \omega_{1}(\tau) d \tau+\int_{L} K_{12}^{*}(t, \tau) \omega_{2}(\tau) d \tau=g_{1}(t), \\
& \left(K_{2} \omega_{1} \omega_{2}\right)(t) \equiv a_{2}(t)\left[\omega_{1}(t)+\bar{t} \omega_{2}{ }^{\prime}(t)-\omega_{2}(t)\right]+ \\
& +\frac{d_{2}(t)}{\pi i} \int_{L} \frac{\omega_{1}(\tau)+\bar{\tau} \omega_{2}{ }^{\prime}(\tau)-\omega_{2}(\tau)}{\tau-t} d \tau+ \\
& +\int_{L} K_{21}(t, \tau) \omega_{1}(\tau) d \tau+\int_{L} K_{22}^{*}(t, \tau) \omega_{2}(\tau) d \tau=g_{2}(t),
\end{aligned}
$$

where

$$
K_{\mathrm{k} 2}^{*}(\mathrm{t}, \tau)=K_{\mathrm{k} 2}(\mathrm{t}, \tau)+\frac{\mathrm{d}_{\mathrm{k}}(\mathrm{t})}{\pi \mathrm{i}} \int_{\mathrm{L}}\left[\frac{\partial}{\partial \tau}\left(\frac{\overline{\mathrm{t}}-\bar{\tau}}{\tau-\mathrm{t}}\right)\right] \mathrm{d} \tau \quad(\mathrm{k}=1,2) .
$$

Introduce auxiliary functions

$$
\begin{aligned}
& \mathrm{W}_{1}(\mathrm{t})=\omega_{1}(\mathrm{t})+\overline{\mathrm{t}} \omega_{2}{ }^{\prime}(\mathrm{t})+\omega_{2}(\mathrm{t}), \\
& \mathrm{W}_{2}(\mathrm{t})=\omega_{1}(\mathrm{t})+\overline{\mathrm{t}} \omega_{2}{ }^{\prime}(\mathrm{t})-\omega_{2}(\mathrm{t}) .
\end{aligned}
$$


The characteristical part of the set (8) considering (9) will be written as:

$$
\begin{aligned}
& \mathrm{a}_{1}(\mathrm{t}) \mathrm{W}_{1}(\mathrm{t})+\frac{\mathrm{d}_{1}(\mathrm{t})}{\pi \mathrm{i}} \int_{\mathrm{L}} \frac{\mathrm{W}_{1}(\tau) \mathrm{d} \tau}{\tau-\mathrm{t}}=\mathrm{f}_{1}(\mathrm{t}), \\
& \mathrm{a}_{2}(\mathrm{t}) \mathrm{W}_{2}(\mathrm{t})+\frac{\mathrm{d}_{2}(\mathrm{t})}{\pi \mathrm{i}} \int_{\mathrm{L}} \frac{\mathrm{W}_{2}(\tau) \mathrm{d} \tau}{\tau-\mathrm{t}}=\mathrm{f}_{2}(\mathrm{t}),
\end{aligned}
$$

where

$$
\begin{aligned}
& \mathrm{f}_{1}(\mathrm{t})=\mathrm{g}_{1}(\mathrm{t})-\int_{\mathrm{L}} K_{11}(\mathrm{t}, \tau) \omega_{1}(\tau) \mathrm{d} \tau-\int_{\mathrm{L}} K_{12}^{*}(\mathrm{t}, \tau) \omega_{2}(\tau) \mathrm{d} \tau, \\
& \mathrm{f}_{2}(\mathrm{t})=\mathrm{g}_{2}(\mathrm{t})-\int_{\mathrm{L}} K_{21}(\mathrm{t}, \tau) \omega_{1}(\tau) \mathrm{d} \tau-\int_{\mathrm{L}} K_{22}^{*}(\mathrm{t}, \tau) \omega_{2}(\tau) \mathrm{d} \tau .
\end{aligned}
$$

The set (10) may be regarded as a set of two independent characteristical singular equations. Regularizing the set (10) by the Carleman method and substituting the reported values in (8), we have

$$
\begin{aligned}
& \omega_{1}(t)+\bar{t} \omega_{2}{ }^{\prime}(t)+\omega_{2}(t)+\int_{L} N_{11}(t, \tau) \omega_{1}(\tau) d \tau+ \\
& +\int_{L} N_{12}(t, \tau) \omega_{2}(\tau) d \tau=f_{1}^{*}(t), \\
& \omega_{1}(t)+\bar{t} \omega_{2}^{\prime}(t)-\omega_{2}(t)+\int_{L} N_{21}(t, \tau) \omega_{1}(\tau) d \tau+ \\
& +\int_{L} N_{22}(t, \tau) \omega_{2}(\tau) d \tau=f_{2}^{*}(t),
\end{aligned}
$$

where $\mathrm{N}_{\mathrm{k}, l}(\mathrm{t}, \tau)(\mathrm{k}=1,2 ; l=1,2)$ are known Fredholm kernels, $f_{k}^{*}(t)$ are known functions.

The set (11) is a set of Fredholm integral equations of the second kind.

Let us make a conclusion as to the index of the set of singular integral equations with the Cauchy kernel (6).

Theorem 1. The system of the singular integral equations with the Cauchy kernel (6) is a Noetherian system. The system index equals to the sum of the indices of the characteristical equations making up the set (10), i.e.

$$
\operatorname{IndW}=\sum_{\mathrm{k}=1}^{2} \operatorname{Ind} \frac{\mathrm{a}_{\mathrm{k}}-\mathrm{d}_{\mathrm{k}}}{\mathrm{a}_{\mathrm{k}}+\mathrm{d}_{\mathrm{k}}} .
$$

In other words the number $p$ is a number of solvability conditions of the set (6) and the number 1 is a number of the linearly independent solutions for the homogeneous set (6) and these numbers are relating as $l-p=\operatorname{Ind} W$.

\section{The stability of the set of singular integral equations with the Cauchy kernel}

Continue solving the set (11) to obtain an answer in an explicit form.

Re-arrange the first integral equation as follows:

$$
\omega_{1}(\mathrm{t})+\int_{\mathrm{L}} \mathrm{N}_{11}(\mathrm{t}, \tau) \omega_{1}(\tau) \mathrm{d} \tau=\mathrm{Q}_{1}(\mathrm{t})
$$

where

$$
\mathrm{Q}_{1}(\mathrm{t})=-\overline{\mathrm{t}} \omega_{2}{ }^{\prime}(\mathrm{t})-\omega_{2}(\mathrm{t})-\int_{\mathrm{L}} \mathrm{N}_{12}(\mathrm{t}, \tau) \omega_{2}(\tau) \mathrm{d} \tau+\mathrm{f}_{1}^{*}(\mathrm{t}) .
$$

Considering the absolute term of the equation (12) known, let us solve the Fredholm integral equation (12) for the unknown function $\omega_{1}(\mathrm{t})$.

$$
\omega_{1}(t)=Q_{1}(t)+\int_{L} R_{1}(t, \tau) Q_{1}(\tau) d \tau+\omega_{10}(t)
$$

where $\omega_{10}(\mathrm{t})$ is a general solution to the homogeneous equation (12), $R_{1}(t, \tau)$ is a generalized resolvent of the integral equation (12). Subject to expression for the function $\mathrm{Q}_{1}(\mathrm{t})$ obtain

$$
\begin{aligned}
& \omega_{1}(t)=-\bar{t} \omega_{2}{ }^{\prime}(t)-\omega_{2}(t)-\int_{L}\left\{R_{1}(t, \tau)+\frac{\partial}{\partial \tau}\left[\tau \cdot R_{1}(t, \tau)\right]\right\} \omega_{2}(\tau) d \tau+f_{1}^{*}(t)+ \\
& +\int_{L} R_{1}(t, \tau) f_{1}^{*}(\tau) d \tau+\omega_{10}(t) .
\end{aligned}
$$
obtain

Substituting (13) into the second integral equation (11),

$$
\begin{aligned}
& \omega_{2}(t)+\frac{1}{2} \int_{L}\left\{N_{21}(t, \tau)-\left[R_{1}(t, \tau)+\frac{\partial}{\partial \tau}\left(\tau \cdot R_{1}(t, \tau)\right]\right\} \omega_{2}(\tau) d \tau=\right. \\
& =\frac{1}{2}\left\{f_{2}(t)-f_{1}^{*}(t)-\int_{L} R_{1}(t, \tau) f_{1}^{*}(\tau) d \tau-\omega_{10}(t)\right\} .
\end{aligned}
$$

The equation (14) is a Fredholm equation of the second kind. In case of its solvability define the function $\omega_{2}(t)$ from the formula

$$
\omega_{2}(t)=Q_{2}(t)+\int_{L} R_{2}(t, \tau) Q_{2}(\tau) d \tau+\omega_{20}(t) .
$$

Substitute the mount of the above into the equation (13). From the equation (13) it is possible to find the function $\omega_{1}(t)$. Notice that $\mathrm{Q}_{2}(\mathrm{t})$ is obtained only through prescribed in the problem situation functions.

Let $\mathrm{g}^{*}{ }_{\mathrm{k}}(\mathrm{t})(\mathrm{k}=1,2)$ be disturbed values of the absolute terms of the set (6). Let the given functions belong to the Hölder class together with their derivatives. The solvability of the set of singular integral equations (6), as the above research shows, does not depend on the absolute terms of the set. Therefore if the unperturbed system (6) is solvable, then the perturbed system (6) also has solutions.

Denote the solutions of the unperturbed system $\left\{\omega_{1}(t), \omega_{2}(t)\right\}$, solutions of the perturbed system $\left\{\omega^{*}{ }_{1}(\mathrm{t}), \omega^{*}{ }_{2}(\mathrm{t})\right\}$.

Subject to the solvability conditions the system of singular Cauchy integral equations (6) is represented by a linear operator 
in the Hölder space $H_{\mu}^{(n)}(L)$ and in the Hölder space with the same criterion $\mu$. Consequently for $\omega_{2}(\mathrm{t})$ it is true that:

$$
\left|\omega_{2}\left(f_{1}, f_{2}\right)-\omega^{*}{ }_{2}\left(f_{1}^{*}, f_{2}^{*}\right)\right| \leq C_{1}\left|f_{1}-f_{1}^{*}\right|^{\mu}+C_{2}\left|f_{2}-f_{2}^{*}\right|^{\mu} \text {. }
$$

Here $\mathrm{C}_{1}$ and $\mathrm{C}_{2}$ are certain constants.

From the equation (16) follows that infinitely small change of the absolute terms of the set of singular integral equations (6) leads to infinitely small change of the functions which are the solutions of the set. Namely, the system (6) is stable against perturbations of its absolute terms.

Regarding the coefficients $a_{k}(t), d_{k}(t)(k=1,2)$ of the set, such conclusion will not be true in the general case. Even arbitrarily small change in the coefficient of the boundary value problem may result in the change of the indices of the singular integral equations of the system ([7] P. 53). In its turn this may lead to the change in the solvability conditions and in the solution form. The very single trivial case when the singular Cauchy integral equations system will be stable against perturbations of the boundary coefficients is the case of the following relation

$$
\text { Ind } \frac{a_{k}-d_{k}}{a_{k}+d_{k}}=0(k=1,2) \text {. }
$$

\section{Conclusions}

The main results are as follows.

We have investigated a system of singular Cauchy equations which is based on the problems of the elasticity theory for isotropic bodies. The system has been tested for stability against perturbations of its absolute terms and boundary coefficients.

It has been proved that a set of singular Cauchy equations on the space of functions satisfying the Hölder condition is stable against perturbation of the constant terms. Namely, infinitesimal changes of absolute terms results in infinitesimal changes of functions which are the system's solution.

In the general case, the set of singular Cauchy equations is unstable against perturbations of the boundary coefficients.

The research has practical application. When solving the primal problems of the elasticity theory, it is necessary to substitute the functions describing outside forces for more 'convenient' from the point of view of numerical techniques. This is among other cases when the body is under the so-called fixed load. Demonstration of the stability of the singular integral Cauchy sets against the perturbations of their absolute terms justifies calculus of approximations in real world tasks.

The boundary nonzero index coefficients emerge in simulation of the so-called mixed primal problems of the elasticity theory. These problems are characteristic by the stresses on the part of the contour defining the body, and by the interchanges on the remaining part of it. Whereby the coefficient forms remain standard and can be easily expressed in polynomials. So calculus for approximations in this case is not needed.

The theoretical value of the study does not come down to the verified propositions only. The set of the singular equations (6) can be used as fundamental for investigating the system stability of the sets of more complex singular integral equations.
For instance, it may be well-applied for sets of singular integral equations with shift. Boundary problems and singular integral equations with a shift emerge in simulation of the primal problems of the elasticity theory for anisotropic medium [6, 7 , $12,13]$.

The set (6) may be applied to studying complete sets of singular and integral Cauchy equations corresponding to fourelement problems for bianalytic functions.

One more avenue of inquiry is connected with extending the class of investigated functions in the Hölder space to a class of random functions converging in the mean square $[3,8]$.

\section{Novelty of the study}

For the first time boundary problems for bianalytic functions were used to investigate the primal problems of the elasticity theory in the works of G.V. Kolosov and N. Muskhelishvili $[10,11]$. D.I. Sherman derived and studied integrals corresponding to the boundary value problems for bianalytic functions $[14,15]$.

Classic problems for polianalytic functions were set by F.D. Gakhov [5]. In [3, 4, 16, 17] there is a careful study of these problems including test stability and solvability.

In $[9,18]$, the authors derived sets of singular Cauchy integrals corresponding to the primal problems of the elasticity theory and to the classic boundary value problems for bianalytic functions.

The test of the singular Cauchy integrals for stability and solvability is a meaningful and essentially new result, obtained by the authors of the given study.

\section{References}

1. Balk M.B. (1991). Polyanalitic functions and their generalization (Polianaliticheskie funkcii $\mathrm{i}$ ih obobshcheniya). Results of science and technology VINITI (Itogi nauki i tekhniki VINITI). Ser. Sovr. Prob. matem. fund. napr. Vol.85. Moscow: VINITI. P. 187-246.

2. Vekua I.N. (1970). On one solution of the primal biharmonic boundary value problem and Dirichlet problem (Ob odnom metode resheniya osnovnoj bigarmonicheskoj kraevoj zadachi i zadachi Dirihle). Some problems of mathematics and mechanics (Nekotorye probl. mat. i mekh.) Leningrad: Nauka. P. 120-127.

3. Volodchenkov A.M., Yudenkov A.V. (2013). Primal problems of the elasticity theory with rectilinear anisotropy in the stochastic potential theory (Osnovnye zadachi teorii uprugosti tel s pryamolinejnoj anizotropiej v stohasticheskoj teorii potenciala). Proceedings: online journal of Kursk State University (Uchenye zapiski: elektronnyj nauchnyj zhurnal Kurskogo gosudarstvennogo universiteta). No. 2 (26). P. 14-17. URL: http://scientific-notes.ru/pdf/030-002.pdf.

4. Volodchenkov A.M., Yudenkov A.V. (2007). Stability of the vector boundary value problem with shift simulating primal problems of the elasticity theory for an anisotropic body (Ustojchivost' vektornoj kraevoj zadachi so sdvigom, modeliruyushchej osnovnye zadachi teorii uprugosti anizotropnogo tela). Survey of applied and industrial mathematics (Obozrenie prikladnoj i promyshlennoj matematiki). Issue 5-6. Moscow. P. 581-583.

5. Gahov F.D. (1977). Boundary value problems (Kraevye zadachi). Moscow: Nauka. 640 p.

6. Lekhnickij G.S. (1977). Elasticity theory of an anisotropic body (Teoriya uprugosti anizotropnogo tela). Moscow: Nauka. $416 \mathrm{p}$. 
7. Litvinchuk G.S. (1977). Boundary value problems and singular equations with shift (Kraevye zadachi i singulyarnye uravneniya so sdvigom). Moscow: Nauka. 448 p.

8. Maksimova L.A., Yudenkov A.V. (2015). Theory of stochastic potential for the two-dimensional elasticity theory (Teoriya stohasticheskogo potenciala $\mathrm{v}$ ploskoj teorii uprugosti). Reporter of Yakovlev Chuvash State Pedagogical University (Vestnik Chuvashskogo gosudarstvennogo pedagogicheskogo universiteta im. I.Ya. Yakovleva). Series: mechanics of the limiting state (Mekhanika predel'nogo sostoyaniya). No. 4 (26). P. 134-142.

9. Maksimova L.A., Yudenkov A.V., Rimskaya L.P. (2016). Generalization of the singular Shermann integral equations with shift for the two-dimensional elasticity theory (Obobshchennye sistemy singulyarnyh integral'nyh uravnenij Shermana so sdvigom v ploskoj teorii uprugosti). Reporter of Yakovlev Chuvash State Pedagogical University (Vestnik Chuvashskogo gosudarstvennogo pedagogicheskogo universiteta im. I.Ya. Yakovleva). Series: mechanics of the limiting state (Mekhanika predel'nogo sostoyaniya). No. 2 (28). P. 15-23.

10. Muskhelishvili N.I. (1966). Certain primal problems of the mathematical elasticity theory (Nekotorye osnovnye zadachi matematicheskoj teorii uprugosti). Moscow: Nauka. 707 p.

11. Muskhelishvili N.I. (1968). Singular integral equations (Singulyarnye integral'nye uravneniya). Moscow: Nauka. 511 p.

12. Redkozubov S.A., Yudenkov A.V., Volodchenkov A.M. (2006). Simulating alteration of a linear elastic homogeneous body with the help of bianalytic functions (Modelirovanie processa linejnoj deformacii uprugogo odnorodnogo tela s pomoshch'yu bianaliticheskih funkcij). Reporter of Yakovlev Chuvash State Pedagogical University (Vestnik Chuvashskogo gosudarstvennogo pedagogicheskogo universiteta im. I.Ya. Yakovleva), No. 1(48). Cheboksary. P. 128-137.

13. Savin G.N. (1975). Stress distribution around holes(Raspredelenie napryazhenij okolo otverstij). Naukova dumka. Kiev.
14. Sherman D.I. (1938). Statistic two-dimensional problem of the elasticity theory for isotropic inhomogeneous media (Staticheskaya ploskaya zadacha teorii uprugosti dlya izotropnyh neodnorodnyh sred). Proceedings of the seismological institute of the Academy of Sciences USSR (Tr. Sejsmol. in-ta AN SSSR). No. 86. P. 1-50.

15. Sherman D.I. (1957). On one elasticity problem with mixed homogeneous conditions (Ob odnoj zadache teorii uprugosti so smeshannymi odnorodnymi usloviyami). Reports of the Academy of Sciences USSR (Dokl. AN SSSR), Vol. 114. No. 4. P. 733-736.

16. Yudenkov A.V. (2002). Boundary value problems with shift for polianalytic functions and their application in the stochastic elasticity theory (Kraevye zadachi so sdvigom dlya polianaliticheskih funkcij i ih prilozheniya k voprosam staticheskoj teorii uprugosti). Smyadyn': Smolensk. 268 p.

17. Yudenkov A.V., Volodchenkov A.M. (2013). Primal problems of the elasticity theory for elastic two-dimensional anisotropic bodies in the stochastic potential theory (Osnovnye zadachi teorii uprugosti tel s pryamolinejnoj anizotropiej v stohasticheskoj teorii potenciala). Proceedings: online journal of Kursk State University (Uchenye zapiski. Elektronnyj nauchnyj zhurnal Kurskogo gosudarstvennogo universiteta). No. 2 (26). P. 14-17.

18. Yudenkov A.V., Rimskaya L.P. (2016). Sets of singular integral equations in the theory of boundary value problems for bianalytic functions (Sistemy singulyarnyh integral'nyh uravnenij v teorii kraevyh zadach dlya bianaliticheskih funkcij). Current topics of the theory of partial equations (Aktual'nye problemy teorii uravnenij $\mathrm{v}$ chastnyh proizvodnyh). Abstracts of the international scientific conference in remembrance of A.V. Bicadze (Tezisy dokladov mezhdunarodnoj nauchnoj konferencii, posvyashchennoj pamyati akademika A.V. Bicadze). P. 146.

19. Balk M.B. (1991). Polyanalytic functions. Berlin: Akademie Verlag. 192 p. 


\section{УСТОЙЧИВОСТЬ СИСТЕМ СИНГУЛЯРНЫХ ИНТЕГРАЛЬНЫХ УРАВНЕНИЙ С ЯДРОМ КОШИ}

Юденков Алексей Витальевич, ФГБОУ ВО СГАФКСТ, г. Смоленск, Россия, aleks-ydenkov@mail.ru Володченков Александр Михайлович, Смоленский филиал РЭУ им. Г.В.Плеханова; Смоленский филиал "СГЮА", 2. Смоленск, Россия, alexmw20I2@yandex.ru

Римская Лилия Павловна, Смоленский филиал РЭУ им. Г.В.Плеханова, г. Смоленск, Россия, lilirimska@yandex.ru

\section{Аннотация}

Сингулярные интегральные уравнения с ядром Коши широко применяются для построения математических моделей реальных физических и технических систем. Они универсальны на всех уровнях моделирования от квантовой теории поля до расчета прочности подземных сооружений. Поэтому исследование устойчивости таких моделей от возмущения, входящих в них свободных членов и коэффициентов является актуальной научной проблемой. Целью исследований является изучение устойчивости системы сингулярных интегральных уравнений с ядром Коши, обобщающих математические модели основных задач теории упругости однородного изотропного тела. Методология исследований основывается на свойствах сингулярного интеграла типа Коши, общей теории нетеровых операторов. В работе системы сингулярных интегральных уравнений сводятся к системе интегральных уравнений Фредгольма второго рода и системе краевых задач для аналитических функций. Основными результатами работы являются: разработка общего метода определения индекса системы сингулярных интегральных уравнений, доказательство устойчивости системы относительно возмущений свободных членов системы. Относительно возмущений краевых коэффициентов система сингулярных интегральных уравнений является неустойчивой. Установление устойчивости сингулярных интегральных уравнений с ядром Коши, обобщающих основные задачи теории упругости, является существенно новым результатом. Исследование систем сингулярных интегральных уравнений проводилось на пространстве функций, удовлетворяющих условию Гельдера. Однако, основные результаты будут справедливы, если рассматривать случайные функции, сходящиеся в среднем квадратическом. Устойчивость систем сингулярных уравнений относительно возмущений свободных членов системы обосновывает применение приближенных численных методов при решении практически важных задач по определению напряженного состояния упругих тел сложной формы.

Ключевые слова: теория упругости, сингулярные интегральные уравнения, теория устойчивости, краевые задачи для аналитических функций, сингулярный интеграл типа Коши.

\section{Литература}

І. Балк М.Б. Полианалитические функции и их обобщения // Итоги науки и техники ВИНИТИ / Сер. Совр. Проб. матем. Фунд. напр. № 85. М.: ВИНИТИ, І99І. С. 187-246.

2. Векуа И.Н. Об одном методе решения основной бигармонической краевой задачи и задачи Дирихле // Некоторые пробл. мат. и мех. Л.: Наука. 1970. С. 120-127.

3. Володченков А.М., Юденков А.В. Основные задачи теории упругости тел с прямолинейной анизотропией в стохастической теории потенциала. Ученые записки: электронный научный журнал Курского государственного университета. 2013. № 2 (26) С. I4-I7. [Сайт]. URL: http://scientific-notes.ru/pdf/030-002.pdf.

4. Володченков А.М., Юденков А.В. Устойчивость векторной краевой задачи со сдвигом, моделирующей основные задачи теории упругости анизотропного тела // Обозрение прикладной и промышленной математики. М., 2007, вып.5-6. С. 58I-583.

5. Гахов Ф.Д. Краевые задачи. М.: Наука, 1977. 640 с.

6. Лехницкий Г.С. Теория упругости анизотропного тела. М.: Наука, 1977. 416 с.

7. Литвинчук Г.С. Краевые задачи и сингулярные уравнения со сдвигом. М.: Наука. 1977. 448 с.

8. Максимова Л.А., Юденков А.В. Теория стохастического потенциала в плоской теории упругости // Вестник Чувашского государственного педагогического университета им. И.Я. Яковлева. Серия: Механика предельного состояния. 2015. № 4 (26). С. $134-\mid 42$.

9. Максимова Л.А., Юденков А.В., Римская Л.П. Обобщенные системы сингулярных интегральных уравнений Шермана со сдвигом в плоской теории упругости. Вестник Чувашского государственного педагогического университета им. И.Я. Яковлева. Серия: Механика предельного состояния. 2016. № 2 (28). С. І5-23.

10. Мусхелишвили Н.И. Некоторые основные задачи математической теории упругости. М.: Наука, 1966.707 с.

I І. Мусхелишвили Н.И. Сингулярные интегральные уравнения. М.: Наука, 1968. 5 I І с. 


\section{TRANSPORT}

12. Редкозубов С.А., Юденков А.В., Володченков А.М. Моделирование процесса линейной деформации упругого однородного тела с помощью бианалитических функций // Вестник Чувашского государственного педагогического университета им. И.Я. Яковлева. №l(48), г. Чебоксары. 2006. С. 128-І37.

13. Савин Г.Н. Распределение напряжений около отверстий. Киев: Наукова думка, 1975.

14. Шерман Д.И. Статическая плоская задача теории упругости для изотропных неоднородных сред. Тр. Сейсмол. ин-та АН СССР, № 86, 1938. С. І-50.

15. Шерман Д.И. О6 одной задаче теории упругости со смешанными однородными условиями. Докл. АН СССР. Т. ІІ4. № 4. 1957. С. 733-736.

16. Юденков А.В. Краевые задачи со сдвигом для полианалитических функций и их приложения к вопросам статической теории упругости. Смоленск: Смядынь, 2002. 268 с.

17. Юденков А.В., Володченков А.М. Основные задачи теории упругости тел с прямолинейной анизотропией в стохастической теории потенциала // Ученые записки. Электронный научный журнал Курского государственного университета. 20I3. № 2 (26). С. $14-17$.

18. Юденков А.В., Римская Л.П. Системы сингулярных интегральных уравнений в теории краевых задач для бианалитических функций.

19. В книге: Актуальные проблемы теории уравнений в частных производных тезисы докладов международной научной конференции, посвященной памяти академика А.В. Бицадзе. 2016. С. 146.

20. Balk M.B. Polvanalvtic functions. Berlin: Akademie Verlag. 1991. 192 p.

\section{Информация об авторах:}

Юденков Алексей Витальевич, ФГБОУ ВО СГАФКСТ, заведующий кафедрой менеджмента и естественно-научных дисциплин, д.ф.-м.н., профессор, г. Смоленск, Россия

Володченков Александр Михайлович, Смоленский филиал РЭУ им. Г.В.Плеханова, заведующий кафедрой естественнонаучных и гуманитарных дисциплин, к.ф.-м.н., доцент; Смоленский филиал "СГЮА", доцент кафедры гуманитарных, социально-экономических и информационно-правовых дисциплин, г. Смоленск, Россия

Римская Лилия Павловна, Смоленский филиал РЭУ им. Г.В.Плеханова, доцент кафедры менеджмента и таможенного дела, к.ф.-м.н., доцент,

2. Смоленск, Россия 